\title{
Variant Developments of Typical Meteorological Years (TMYs) for Seeb, Oman and their Impact on Energy Simulation of Residential Buildings
}

\author{
N.A. Al-Azri*, a, and S. Al-Saadib \\ a Department of Mechanical and Industrial Engineering, Sultan Qaboos University, PO Box 33, Al-Khoud 123, Oman. \\ ${ }^{b}$ Department of Civil and Architectural Engineering, Sultan Qaboos University PO Box 33, Al-Khoud 123, Oman.
}

Received 20 June 2016; Accepted 28 January 2018

\begin{abstract}
Typical meteorological years (TMYs) are widely used for the analysis and simulation of energyintensive systems. The reliability of a developed typical year depends on the accuracy of the historical record of weather data as well as the fitness of the developed approach to the application. In this work, a TMY for Seeb area in the Muscat Governorate, Oman was developed using different approaches. The developed TMYs are compared to the current commonly used TMY which is based on 1985-2001 records that have many gaps and anomalies and hence have intensive interpolation treatment. The different TMYs were compared by simulating energy consumption of a typical residential building and also by studying applicability of passive cooling strategies. The findings showed that the variation in energy consumption is minimal for the different TMY development approaches for the same set of historical records but the difference is very significant when the comparison is based on the two sets from the two periods of records.
\end{abstract}

Keywords: Typical meteorological year (TMY); Weather data; Passive cooling.

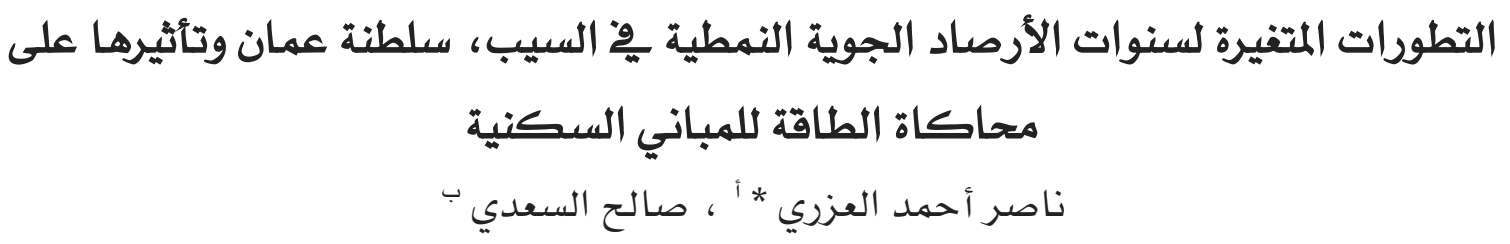

الملاخص: تستخدم سنوات الأرصاد الجوية النمطية على نطاق واسع لتحليل وهحاكاة أنظمة استهالاك الطاقة الكثيفة. تعتمد موثوقية السنة النمطية المتقدمة على دقة السجل التاريخي لبيانات الطقس بالإضافة إلى مدى ماللامة أسلوب بناء السنة النموذجية للاستخدام المستهدف. پوْ هذا العمل، تم تطوير سنة الارصاد النمطية لمنطقة السيب وِ محافظة مسقط، عمان باستخدام أسـاليب مختلفة .حيث تمت مقارنة سنوات الأرصاد الجوية النمطية المطورة مع سنة الارصاد النمطية المستخدمة بشكل شائع

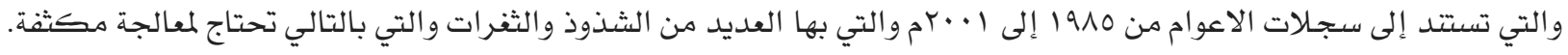
وتمت مقارنة سنوات الأرصاد الجوية النمطية المختلفة من خلال محاكاة استهلاك الطاقة لمبنى سكني نهوذجي وأيضا من خلال دراسـة إمكانية تطبيق استراتيجيات التبريد السلبي · وأظهرت النتائج أن التباين فِ استهلاك الطاقة ضئيل بالنسبة لاساليب التطوير المختلفة لسنة الارصاد النمطية لنفس مجموعة السجلات التاريخية ولكن هذا الفرق كبير عندما تكون المقارنة مبنية على مجموعتين من فترتي التسـجيل. الكلمات المفتاحية: سنة الأرصاد الجوية النمطية ، بيانات الطقس، التبريد السلبي • * Corresponding author's e-mail: nalazri@squ.edu.om 


\section{Introduction}

Typical meteorological years (TMYs) are used by a wide spectrum of professionals in designing and studying climate-dependent cases. A TMY is a set of year-long data, statistically selected from a historical record of metrological data and it is regarded as the best representation of the climatic behavior in a given location throughout the year.

TMYs were first developed in the United States for 229 locations using solar radiation and weather records from 1948 to 1980. That collection was updated twice using data for the periods 1961-1990 and 1991-2005 for 1020 locations in the second update.

Typical meteorological years are essential in simulating long-term weather-dependent projects such as estimating cooling and heating loads and building renewable energy harvesting facilities. Basing simulation on weather data from a random actual year will make the results susceptible to underestimation and overestimation due to the likely variation in weather behavior. Hence, TMYs are only good when an average weather behavior is under consideration and they should not be used for extreme weather conditions.

The reliability of TMYs depends on the accuracy of the historical record and the fitness of the development methodology for the targeted application. The typical meteorological year is composed of the typical months in the historical records eg. typical January is January of one of the years in the full record that is statistically the best representative of the common trend in the weather during the month of January. The typical month is basically the month whose weather parameters are the closest to the mean of all months in the historical record. The more relevant parameters are assigned the higher weight in the statistical methodology and hence have higher impact on whether to select a given month.

The TMY currently used for Seeb area in Muscat Governorate, Oman is based on a historical record from 1985 to 2001. Like most of the records around that period in Oman, it suffers from many gaps and anomalies.

This work aims at updating the TMY used in Seeb, Governorate of Muscat, Oman and assessing the impact of using TMYs that are based on different historical records and developed using different approaches. In this work, the developed typical metrological year is based on a more accurate and recent record from 2000 to 2014. The new TMY is compared to the old one based on the energy consumption and capital cost of a typical residential building in order to study the variation when two historical records are used. Moreover, different development methods are compared based on the 2000-2014 record.

Passive cooling strategies are based on bioclimatic charts which are based on dry bulb temperature and dew point, usually taken from a typical metrological year. In order to study the impact of the application on the reliability of the developed TMY, a TMY is developed with all the weight assigned to the two relevant parameters and zero weight assigned to solar radiation. Bioclimatic charts and the applicability of passive cooling strategies are then based and compared on the two sets of TMYs.

This research sheds light on the reliability of the currently used TMYs in Oman and the need for updating them. It also tackles the impact of using different approaches in developing TMYs on the simulation results of energy systems. It also addresses the impact of using TMYs based on inaccurate records on bioclimatic charts and it stresses the urgency for examining the quality of the data set when developing TMYs.

\section{TMY Development}

The development of the TMY is based on statistical methodology in which data from historical archives are selected to represent a typical year. The TMY was first developed by Sandia laboratories, USA and it was intended for solar heating and cooling purposes Habte $e t$ al. (2014).

The Sandia procedure is thoroughly explained in the work of Sawaqed et al. (2005). The method in its original version is based on the daily averages of the nine parameters listed in Table 1 except the direct radiation. Each of these parameters is statistically analyzed over a recommended period of 12-24 years. Then Finkelstein-Schafer statistic Finkelstein and Schafer (1971) is used to indicate the deviation of the short term daily mean of the nine parameters (using cumulative distribution function) from their daily averages over the value for all years in the record, which is known as long term cumulative distribution function. Then, a weighted sum of the average daily deviations (Finkelstein-Schafer statistic) is calculated. For each month in the year, five best candidate years are selected according to the 
least weighted deviations. In order to reassure that this selection was not a result of some anomalies, further screening is performed by checking the deviation of the mean and median for each month from the long term means and medians and also checking the run count and length in each month as described by Sawaqed et al. (2005).

Most TMY development methods are based on the Sandia method but mainly differ in the weights assigned to each of the contributing parameters in the calculation of FinkelsteinSchafer statistic as shown in Table 1. These weights are usually selected based on the purpose for which TMY is developed. The weights shown in Table 1 are intended for general simulation of thermal applications and are not valid for case analysis at extreme weather conditions. The weights suggested by Sandia were adopted in the generation of the first version of TMYs in the United States and also in many other works, eg. Petrakis et al. (1996). Other applications of Sandia used different weights. For instance, Pissimanis et al. (1988) gave no weight to all parameter ranges in addition to the minimum wind speed. Sawadeq et al. (2005) adopted the same weights as in Sandia but gave no weight to the minimum wind speed. However, Sawadeq et al. (2005) replaced the dew point with relative humidity. Subsequent generations of TMYs in the United States; TMY2 (Marion et al. 1995) and TMY3 (Wilcox et al. 2008) also excluded the ranges and the minimum wind speed but added direct radiation to the list of parameters.

In addition to the purpose of use, the selection of these weights is also intended for increasing the agreement with the historical record. For example, the adoption of direct radiation in TMY3 improved the agreement between annual direct normal radiation for the typical year and the record of the 30-year annual average by a factor of two (Wilcox and Marion, 2008). Moreover, the wind velocity is given less weight while increasing the weights of dry bulb and dew point temperatures, which are more important in solar energy conversion systems and buildings. Hence, this modification has rendered TMY3 inappropriate for wind energy applications (Wilcox and Marion, 2008).

In addition to the Sandia method, which is the classical development algorithm, heuristic methodologies are also used, in which, machine learning algorithms are used in developing weather files (Chakraborty et al. 2016).

Table 1. The different weights used in different works in the development of the TMY.

\begin{tabular}{lcccc}
\hline Parameter & Sandia $^{\mathbf{a}}$ & $\begin{array}{c}\text { Pissimani } \\
\text { et al. }\end{array}$ & TMY2/3c & $\begin{array}{c}\text { Sawaqed } \\
\text { et al.d,e [14] }\end{array}$ \\
\hline Max dry bulb temp & $1 / 24$ & $1 / 24$ & $1 / 20$ & $1 / 22$ \\
Min dry bulb temp & $1 / 24$ & $1 / 24$ & $1 / 20$ & $1 / 22$ \\
Mean dry bulb temp & $1 / 24$ & $2 / 24$ & $2 / 20$ & $1 / 22$ \\
Dry Bulb Temp range & $1 / 24$ & 0 & 0 & $1 / 22$ \\
Max dew point temp & $1 / 24$ & $1 / 24$ & $1 / 20$ & $1 / 22$ \\
Min dew point temp & $1 / 24$ & $1 / 24$ & $1 / 20$ & $1 / 22$ \\
Mean dew point temp & $1 / 24$ & $2 / 24$ & $2 / 20$ & $1 / 22$ \\
Dew point temp range & $1 / 24$ & 0 & 0 & $1 / 22$ \\
Max wind velocity & $1 / 24$ & $2 / 24$ & $1 / 20$ & $1 / 22$ \\
Min wind velocity & $1 / 24$ & 0 & 0 & 0 \\
Mean wind velocity & $1 / 24$ & $2 / 24$ & $1 / 20$ & $1 / 22$ \\
Wind velocity range & $1 / 24$ & 0 & 0 & $1 / 22$ \\
Global radiation & $12 / 24$ & $12 / 24$ & $5 / 20$ & $11 / 22$ \\
Direct radiation & 0 & 0 & $5 / 20$ & 0 \\
\hline aHall et al. (1978) & \multicolumn{5}{l}{ bPissimanis et al. (1988) } \\
cMarion and Urban (1995) and Wilcox and Marion (2008) \\
dSawaqed et al. (2005) \\
eThe relative humidity is used in place of dew point temperature.
\end{tabular}




\section{Building Simulation and Weather Files}

Building simulation software programs are primarily used to perform energy and thermal analyses of buildings. Energy is analyzed based on hourly or sub-hourly basis in order to capture the dynamic behavior of building systems. In the energy analysis procedure, a typical weather file should be derived from raw data of many years. Many typical weather data sets are internationally recognized for use in detailed energy simulation programs. In North America, well-known weather data sets are used which include: Typical Reference Year (TRY, the American version) (NCDC, 1976), Typical Metrological Year (TMY, TMY2 and TMY3) Wilcox and Marion (2008), Weather Year for Energy Calculation (WYEC), Canadian Weather for Energy Calculations (CWEC) WATSUN (1992), and Weather Year for Energy Calculation Version: 2 (WYEC2) (Huang J, 1998; Stoffel and Rymes, 1998). For the U.S.A. TMY files are commonly developed for hundreds of locations and some states like California has its own weather data set (California Thermal Zone Version2: CTZ2) which is used for the state code compliance. In Canada, CWEC weather data set is commonly used but WYEC2 format is also used for some locations. In Europe, the standard method of generating Test Reference Year (ISOTRY version) is proposed under ISO Standard prEN ISO 15927-4 (Levermore and Doylend, 2002). Another form of TRY is proposed by Chartered Institution of Building Services Engineers (CIBSE) in the U.K. (Holmes and Hitchin, 1978). The ISO-TRY is proposed for near-extreme plant design or near-extreme performance assessment whereas the CIBSETRY format is for average energy estimation and analysis. Therefore, ISO-TRY is more appropriate for HVAC Design and short-term performance analysis.

Many endeavors were dedicated to establishing suitable weather data files for energy simulation programs (Clarke 2001). The American Society of Heating, Refrigerating, and Air-Conditioning Engineers (ASHRAE) developed typical weather years, which are known as International Weather for Energy Calculation (IWEC), for nearly three thousand sites outside US and Canada (ASHRAE 2015). Due to the lack of solar radiation data, solar radiation algorithms were used to generate the IWEC. The weather data years are selected based on the standard methodology of TMY2 (Marion and Urban, 1995), which is also based on Sandia method.

The types of different weather data sets and the selection methodologies of a typical weather year have brought about many issues related to the reliability of energy simulation. This problem has been addressed by Crawley et al. (1999). In their study, a typical office building was simulated in eight U.S. locations using different reference years (TRY, TMY, TMY2, WYEC, WYEC2) based on a 30-year-period of actual hourly weather data. Crawley studied the impact of using various weather data sets on the annual energy use and costs and the annual peaks of electrical demand, heating load, and cooling load. The study concluded that the American version of TRY-type weather data should be avoided since no single year can represent the typical long-term weather patterns. TMY2 and WYEC2 were found more rigorous in predicting the energy consumption since improved solar models are used in simulating solar radiation. Therefore, they are regarded as the best representative of long-term average climatic conditions. Huang (1998) conducted another study in which he evaluated the influence of different sets of weather data, also based on a 30-year-period of historical records, on residential buildings. The study concluded that TMY2 and WYEC2 weather data gives results within $5 \%$. The study justified the use of the typical weather year to simulate the peak building loads because the selection process doesn't eliminate the peak design conditions. It was also concluded that the American version of TRY is less reliable in replicating the average historical conditions. Erba et al. (2017) studied the effect of weather datasets on building energy simulation outputs for a public social housing block located in the area of Milan, Italy. In their study, they found a difference in the output results when they used two commonly used weather datasets. In their conclusion, they asserted the need for updating weather files for more accurate simulation.

\section{Using TMY for Passive Cooling}

Passive cooling techniques are used in minimizing the load on mechanically-driven cooling devices. In general, the selection of building passive thermal design strategies is based on dry bulb temperature and humidity. Identifying suitable strategies for a given 
location can be made using bioclimatic charts. Olgyay's bioclimatic chart (Olgay 1963) developed in the 1950s, was one of the first attempts for identifying the best passive cooling methods. Nowadays, there are a number of approaches for developing bioclimatic charts, and these mostly have outlined zones for each passive method overlaid on a psychrometric chart. Figure 3 shows Giovoni's bioclimatic chart in which there are five passive cooling zones: comfort zone, natural ventilation, high mass, high mass with night ventilation and evaporative cooling. Extensive description on passive cooling techniques and the development of bioclimatic charts is available in the literature (Al-Azri et al. 2013).

Another more popular bioclimatic chart is that of Givoni (1992; 1994). This chart is based on the linear relationship between the temperature amplitude and vapor pressure of the outdoor air. Givoni's chart identifies the suitable cooling technique based on the outdoor climatic condition. Five zones are identified on Givoni's chart: thermal comfort, natural ventilation, high mass, high mass with night ventilation and evaporative cooling.

Givoni's Bioclimatic charts are utilized by first identifying the average monthly conditions. For each month, the average of the daily maximum temperature is calculated and matched with the average of the minimum daily absolute humidity to form the point $\left(\bar{T}_{\text {max }}, \bar{w}_{\text {min }}\right)$. Likewise, the average of the daily minimum temperature is matched with that of the average daily minimum absolute humidity to form $\left(\bar{T}_{\min }, \bar{w}_{\max }\right)$. The placement of the line segment connecting the two points will determine the proper passive cooling strategy for that month.

Givoni's chart is mainly applicable to residential and office buildings where heat gain is minimal. Modifications to Givoni's chart that suit nondomestic buildings can also be found in the literature (Lomas et al. 2004). The natural ventilation zone on Givoni's chart assumes that the indoor mean radiant temperature and the vapor pressure are the same as those at outdoor conditions; an assumption that limits the application to buildings with medium to high thermal structure (Watson 1981).

A more accurate representation of the typical metrological year for the development of the bioclimatic charts can be developed by eliminating irrelevant parameters, such as wind speed and solar radiation, in Sandia procedure and dedicating all the weight to dry bulb temperature and dew point (Al-Azri 2016).

\section{The Study}

Weather and solar radiation data for the Seeb area were collected for the period 2000-2014 which feature better accuracy and fewer gaps and anomalies compared to the data used in previous studies. The time reference point for the data was taken at the beginning of the hour and hence data taken at fractions of the hour were interpolated with the adjacent readings using linear interpolation provided that the end points of the interpolation period does not exceed 60 minutes. The data was then qualitychecked by investigating missing points and anomalies. Unrealistic anomalies were removed and regarded as missing points. Missing points were found to be around $2 \%$ in the whole set and their consecutive occurrences extend for different periods mostly for a few hours. Periods of missing points up to two hours where lineally interpolated with the adjacent readings. Consecutive missing points for longer periods where linearly interpolated using readings from the adjacent days at the same period of time in the day. In the development of the TMY, the same procedure described by Sawaqed et al. (2005) was followed but using the different weights shown in Table 1.

In this paper, different approaches for typical metrological years are studied for Seeb area in Muscat Governorate, Oman. The weather data were taken for Muscat Airport station, which is located at $23.583^{\circ}$ latitude and $58.283^{\circ}$ longitude and it is 8.4 meter above sea level.

Two sets of records for this station were used; the old 1985-2001 record and the new 2000-2014 record. The two sets have distinct features. The old record, upon which the current TMY was developed, has many anomalies and its solar radiation data were calculated using the daily mean values.

\section{Simulation of a Typical Residential Unit}

Simulation programs are commonly used for the design of energy-efficient buildings. These tools are primarily used for energy analysis but can also be helpful when sizing air conditioning systems. For the purpose of this study, QUick Energy Simulation Tool (eQuest) is utilized for yearly simulation (LBNL and JJH 1998). A typical residential building shown in Fig. 1 is 
assumed to be the representative house in construction details are defined in Table 2 . Oman. The physical, thermal characteristics and

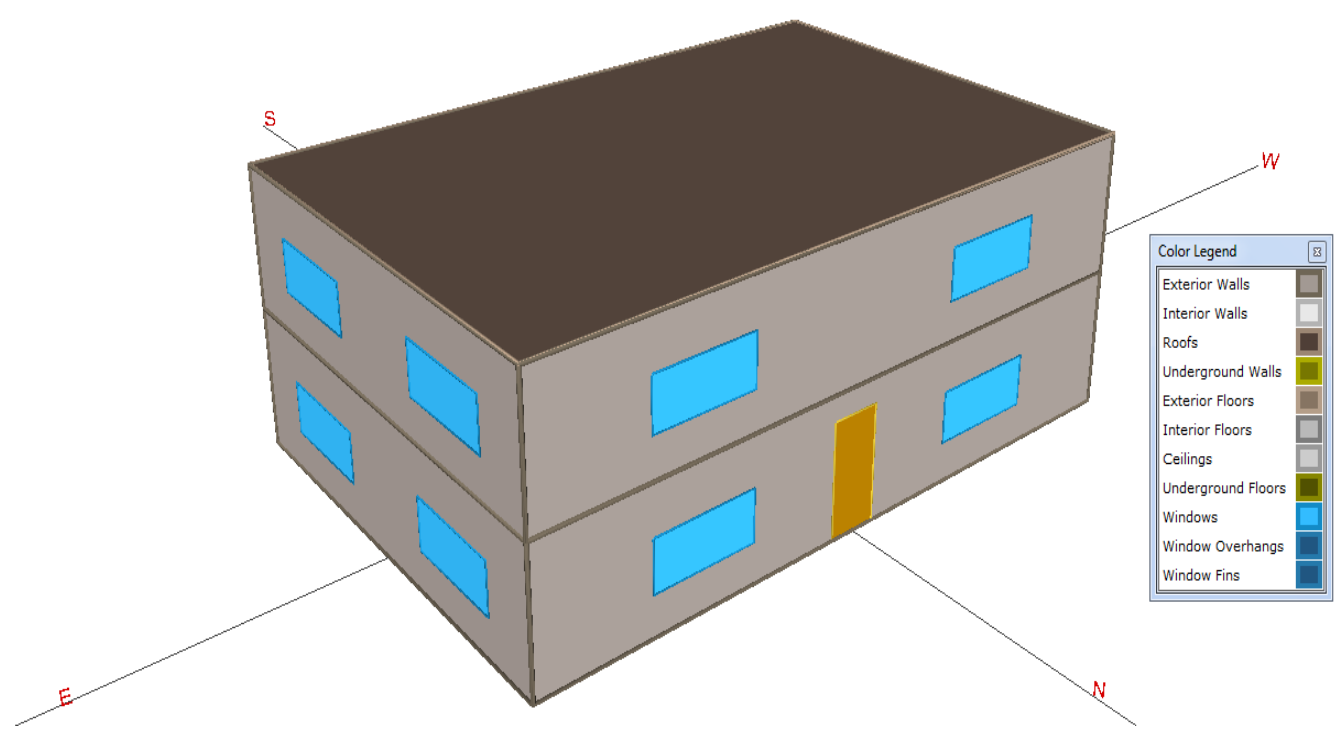

Figure 1: 3D view of the typical housing in eQuest.

Table 2. Characteristics of building systems for a typical residential housing in Oman.

\begin{tabular}{|c|c|}
\hline Characteristics & Description of the Base Case \\
\hline Location & Seeb, Oman \\
\hline Orientation & Front Elevation facing North \\
\hline Plan Shape & Rectangular \\
\hline Number of floor & Two thermal zones: living area and sleeping area \\
\hline Floor to Floor Height & $3.35 \mathrm{~m}(11 \mathrm{ft})$ \\
\hline Floor Area & $240 \mathrm{~m}^{2}\left(2582 \mathrm{ft}^{2}\right)$ \\
\hline Floor Dimension & $12.5 \times 19.2 \mathrm{~m}(41.5 \times 62.3 \mathrm{ft})$ \\
\hline Window Area & $15 \%$ of the gross wall area, Uniformly Distributed \\
\hline \multirow[t]{2}{*}{ Window } & Type of Glass: 4 mm Single Green Tinted Glazing \\
\hline & Frame: Aluminum with no thermal break \\
\hline Solar Absorbance & 0.50 for external walls (medium color) \\
\hline Exterior Walls & $\begin{array}{l}0.50 \text { for the roof ( medium color }) \\
15 \mathrm{~mm} \text { cement plaster }+200 \mathrm{~mm} \text { CMU hollow block }+15 \mathrm{~mm} \text { cement } \\
\text { plaster }\end{array}$ \\
\hline Roof & $\begin{array}{l}\text { Tiles + } 10 \text { mm Mortar + } 150 \text { mm reinforced concrete slab + } 15 \text { mm } \\
\text { Cement Plaster }\end{array}$ \\
\hline Floors & $\begin{array}{l}\text { Ground floor: } 300 \mathrm{~mm} \text { soil }+200 \mathrm{~mm} \text { slab on grade, Intermediate floor: } \\
150 \mathrm{~mm} \text { reinforced concrete slab }\end{array}$ \\
\hline Shading & Interior shades when zones are occupied \\
\hline Occupancy Density & 6 People \\
\hline Lighting Power Density & $5 \mathrm{~W} / \mathrm{m}^{2}$ (for Ground and 1stFloor) \\
\hline Equipment Power & $8.5 \mathrm{~W} / \mathrm{m}^{2}$ (for Ground and $1^{\text {st }}$ Floor) \\
\hline Density & \\
\hline Infiltration & $0.75 \mathrm{ACH}$ \\
\hline System Type & Split air-conditioning units (Constant-Volume DX AC) \\
\hline Thermostat Setting & $24^{\circ} \mathrm{C}$ for Cooling (no heating is provided) \\
\hline COP & 2.8 \\
\hline
\end{tabular}


Figure 2 shows the monthly electrical consumption and energy cost for the house when a weather file from Meteonorm software is used (Meteonorm 7, 2015). For comparison, a recent survey study for 50 houses in Seeb, Oman indicated that actual annual energy consumption ranges between 16-82 MWh of electricity in a year, with an average of 44 MWh/year (Al-Hashim 2013). The eQuest software predicts an electrical consumption of 48.2 MWh/year for the base case model considered in this study.

In addition to the weather file generated by Meteonorm software (Meteonorm 7, 2015), the building simulation model is used with different weather files developed in this research based on approaches described in the literature (Hall et al. 1978; Pissimanis et al. 1988; Sawaqed et al. 2005; Wilcox and Marion, 2008). Using the TMY approach described by Sawaqed et. al. (2005), two weather files using two different raw weather datasets were generated; one TMY file based on weather data from the period 1985-2001, and another TMY file is based on weather data for the period 2000-2014. The

other TMY files described by Hall et al. (1978), Pissimanis et al. (1988), Sawaqed et al. (2005) and, Wilcox and Marion (2008) were all generated using weather dataset of 2000-2014.

The development of the weather files are based on the weights given in Table 1. Table 3 shows the typical years selected by the different approaches.

Despite the variations in the assigned weights, the different approaches merged to almost an identical typical years except for a few months. In general, Wilcox' approach exhibits the most variation as it differs from the others in five months which can be attributed to the fact that this approach carry an additional parameter, namely, direct radiation, assigned $25 \%$ of the weight which has influenced the selection process. This variation, however, might not have any impact on the simulation as the hourly variation in the climatic readings of the different months might behave in a similar manner whose impact on energy analysis is minimal. This fact will be more elaborate in the results of the simulation.

\section{$\rightarrow$ Electrical Cost}

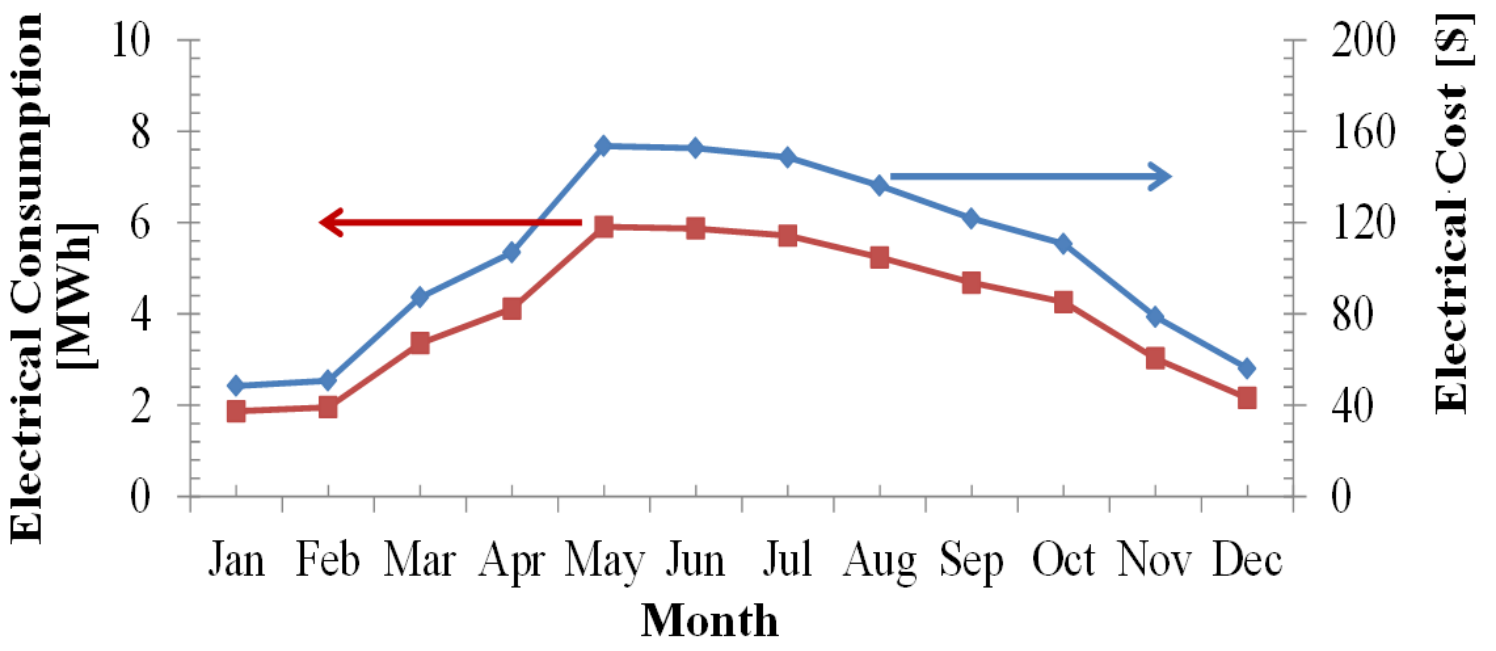

Figure 2. Monthly electrical consumption/cost for the house using weather file from Meteonorm software.

Table 3. The typical years selected for each month using different approaches.

\begin{tabular}{lllllllllllll}
\hline TMY Approach & Jan & Feb & Mar & Apr & May & Jun & Jul & Aug & Sep & Oct & Nov & Dec \\
\hline Sandia & 2009 & 2012 & 2007 & 2014 & 2013 & 2012 & 2010 & 2009 & 2005 & 2002 & 2012 & 2007 \\
Pissimanis & 2009 & 2002 & 2007 & 2014 & 2013 & 2012 & 2010 & 2009 & 2005 & 2002 & 2012 & 2007 \\
TMY2/3 & 2005 & 2002 & 2011 & 2007 & 2013 & 2012 & 2010 & 2009 & 2001 & 2006 & 2012 & 2007 \\
Sawadeq, 2005 & 1995 & 1994 & 1993 & 1988 & 1994 & 1987 & 1996 & 1989 & 1994 & 1989 & 1986 & 1987 \\
Sawadeq, 2005b & 2009 & 2012 & 2007 & 2014 & 2013 & 2012 & 2010 & 2009 & 2005 & 2005 & 2012 & 2007 \\
\hline a Based on 1985-2001 dataset and b Based on 2000-2014 dataset.
\end{tabular}


Meteonorm weather files are commonly utilized in building simulation tools. Hence, it is used here as the base case for comparison. Two performance indicators are extracted from the eQuest simulation files: the annual space cooling energy ( $\mathrm{kWh}$ /year) and the peak space cooling load (tons). The associated costs for these two indicators are provided for comparison using the local electrical cost of $0.026 \$ / \mathrm{kWh}$ and capital equipment cost of $\$$ $260 /$ Ton. Table 4 shows the results when using all six TMY weather files. The absolute and relative differences for the associate costs are calculated. The negative sign of the relative difference indicates that the results of the simulated cases are lower than the base case (ie. Meteonorm TMY weather file).

Regardless of the TMY approach used, the results based on the 2000-2014 dataset show low deviation from the reference case (lower by 1.9$2.4 \%)$. For the same dataset and its derived TMY weather files, the result for the peak cooling load is identical and lower by $\sim 16 \%$ when compared to the base case. In all TMY files, the peak month, which is used for peak calculation is the same, June 2012, which explains the similarity amongst the results.

The results predicted by the TMY file developed from 1985-2001 dataset using the Sawaqed's (2005) approach is $14 \%$ and $11 \%$ lower than the base case for annual cooling energy and peak cooling load, respectively. This dataset was based on an older record and its solar radiation data was modeled using monthly averages. In terms of accuracy, the 2000-2014 dataset is better and hence the results using TMY based on this set should be more credible.

\section{Passive Cooling in Seeb}

In order to study the impact of variation in typical meteorological years, bioclimatic charts are developed for Seeb using the same dataset but different approaches and using the same approach with different datasets. The two results are compared to the base TMY of Meteonorm. The first dataset was taken from 1985-2001 in which the approach of Sawadeq et al. (2005) was used. The other dataset was taken from 2000-2014 and features minimal missing data and hourly solar radiation measurements, unlike the older set in which radiation was modeled from monthly averages. As shown in Table 3, the behavior of the different approaches and weights is almost identical when the same dataset is used in the development of the TMY. Hence, Sawadeq et al. (2005) approach is used for both sets; 1985-2001 and 2000-2014. Figures 3 and 4 shows the bioclimatic charts using both datasets.

Table 4. Impact of weather files on annual cooling energy consumption, peak cooling load and the associated costs.

\begin{tabular}{|c|c|c|c|c|c|c|c|}
\hline Reference & Dataset & $\begin{array}{c}\text { Annual } \\
\text { Cooling } \\
\text { ( kWh) }\end{array}$ & $\begin{array}{c}\text { Annual } \\
\text { Cooling } \\
\text { (\$) }\end{array}$ & $\begin{array}{c}\text { Difference } \\
\text { in Annual } \\
\text { Cooling } \\
(\% \$)\end{array}$ & $\begin{array}{l}\text { Peak } \\
\text { Load } \\
\text { (Tons) }\end{array}$ & $\begin{array}{c}\text { AC } \\
\text { Capital } \\
\text { Cost, \$ }\end{array}$ & $\begin{array}{c}\text { Difference } \\
\text { in Capital } \\
(\% \$)\end{array}$ \\
\hline $\begin{array}{l}\text { (Meteonorm } \\
7,2015)^{\mathrm{a}}\end{array}$ & 2000-2009 & 31,587 & 821.3 & - & 20.1 & 5,226 & - \\
\hline $\begin{array}{l}\text { (Pissimanis et } \\
\text { al., 1988) }\end{array}$ & 2000-2014 & 30,823 & 801.4 & $\begin{array}{c}19.9 \\
(-2.4 \%)\end{array}$ & 16.9 & 4,394 & $\begin{array}{c}832 \\
(-15.9 \%)\end{array}$ \\
\hline $\begin{array}{l}\text { (Wilcox \& } \\
\text { Marion, 2008) }\end{array}$ & $2000-2014$ & 31,092 & 808.4 & $\begin{array}{c}12.9 \\
(-1.6 \%)\end{array}$ & 16.9 & 4,394 & $\begin{array}{c}832 \\
(-15.9 \%)\end{array}$ \\
\hline $\begin{array}{l}\text { (Sawaqed et } \\
\text { al., 2005) }\end{array}$ & $1985-2001^{b}$ & 27,032 & 702.8 & $\begin{array}{c}118.5 \\
(-14.4 \%)\end{array}$ & 17.8 & 4,628 & $\begin{array}{c}598 \\
(-11.4 \%)\end{array}$ \\
\hline $\begin{array}{l}\text { (Sawaqed et } \\
\text { al., 2005) }\end{array}$ & $2000-2014$ & 30,833 & 801.7 & $\begin{array}{c}19.6 \\
(-2.4 \%)\end{array}$ & 16.9 & 4,394 & $\begin{array}{c}832 \\
(-15.9 \%)\end{array}$ \\
\hline $\begin{array}{l}\text { (Petrakis et } \\
\text { al., 1996) }\end{array}$ & 2000-2014 & 30,823 & 801.4 & $\begin{array}{c}19.9 \\
(-2.4 \%)\end{array}$ & 16.9 & 4,394 & $\begin{array}{c}832 \\
(-15.9 \%)\end{array}$ \\
\hline
\end{tabular}

aReference case, bSolar radiation is not measured in this station and based on 1985-2001 dataset. 
The solid lines in both graphs indicate the results projected by the TMY based on Meteonorm while the dashed lines are those taken from the two records of datasets. When compared with each other, the distribution pattern is the same for the Meteonorm TMY and those developed from the two datasets. However, the representation of the older dataset is more similar to that of Meteonorm where all counterpart months are close enough and intersect one another. The observation is so different with the newer dataset (2000-2014) that in some cases a technique is suggested by one TMY but not by the other. For instance, the two lines of June lie far apart; while in Meteorm set it suggests mechanical air conditioning, the 2000-2014 set suggests that high mass will work at high temperature values.

The comparison is quantified in Table 5 which shows the percentage of readings falling on each zone using Metenorm TMY (set A), TMY developed from 1985-2001 dataset (set B) and TMY developed from 2000-2014 dataset (set C).

The three sets, in many cases, exhibit wide differences. However, sets A and B are closer to each other than A and C.

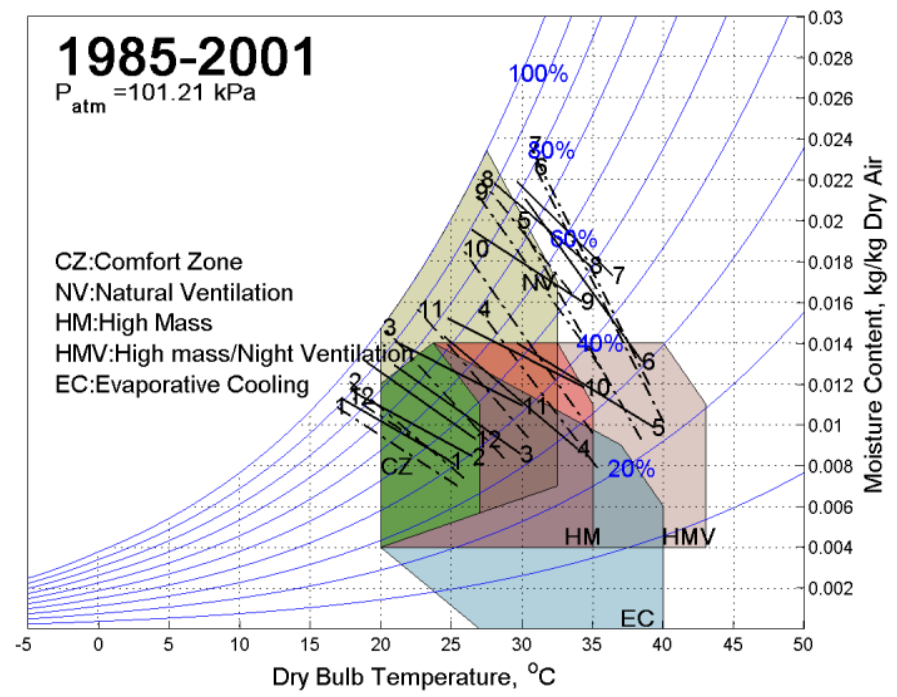

Figure 3. Givoni bioclimatic chart using TMY developed by Sawaqed et al. (2005) using 1985-2001 dataset.

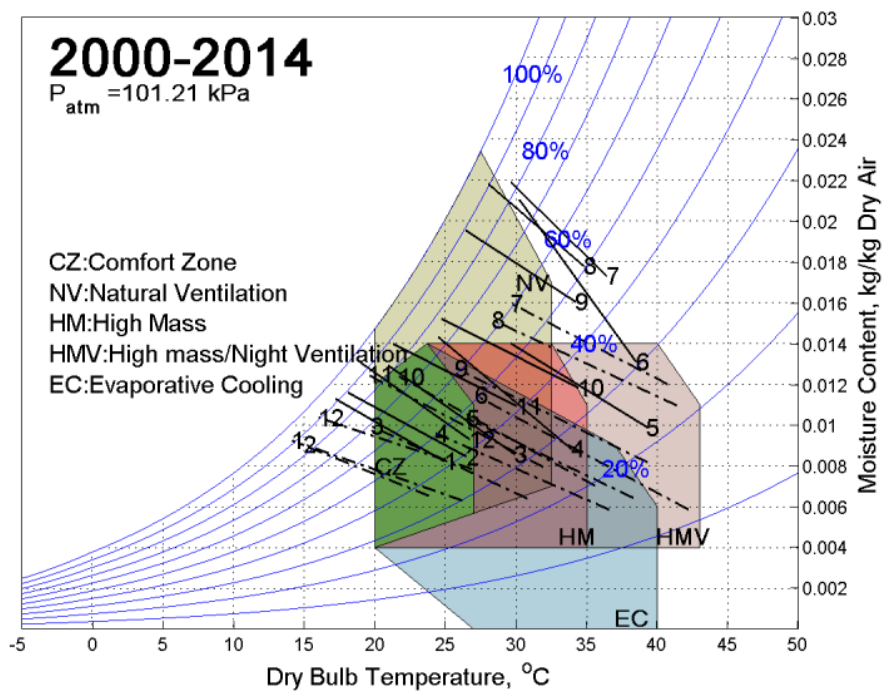

Figure 4. Givoni bioclimatic chart using TMY developed by Sawaqed et al. (2005) using 2000-2014 dataset. 
Unlike the simulation of active cooling system, the deviation from the base set (A) here is exhibited more in the 2000-2014, set (C), than it is in the 1985-2001 set (B). This is due to the fact that in the bioclimatic charts only humidity and temperature that are considered. The development of the bioclimatic chart is dependent based on the average minima and maxima of these parameters; while in the active cooling simulation, radiation was also part of the simulation.

Figure 5 and Fig. 6 show the monthly mean dry bulb temperature in Seeb for all years in the
2000-2014 record and the year chosen to be the typical meteorological year (bold curve). In Figure 6, all parameters are considered in the development of the TMY, with the mean dry bulb temperature carries $10 \%$ of the weight based on TMY2/3 approach. Figure 7 considers dry bulb temperature and dew point only, which are the relevant ones to the development of the bioclimatic charts with mean dry bulb temperature caries $20 \%$ of the weight while the $80 \%$ are assigned to mean dew point $(20 \%)$, minimum, maximum and range of dry bulb and dew point (10\% each).

Table 5. The percentage of hours falling on each zone using Meteonorm (A), 1985-2001 (B) and 20002014 (C) TMY.

\begin{tabular}{c|ccc|ccc|ccc|ccc|ccc}
\hline & \multicolumn{3}{|c|}{ Comfort zone } & \multicolumn{3}{c|}{$\begin{array}{c}\text { Natural } \\
\text { ventilation }\end{array}$} & \multicolumn{3}{c|}{ High mass } & \multicolumn{3}{c|}{$\begin{array}{c}\text { High mass } \\
\text { /night }\end{array}$} & \multicolumn{3}{c}{$\begin{array}{c}\text { Evaporative } \\
\text { cooling }\end{array}$} \\
\hline & $\mathrm{A}$ & $\mathrm{B}$ & $\mathrm{C}$ & $\mathrm{A}$ & $\mathrm{B}$ & $\mathrm{C}$ & $\mathrm{A}$ & $\mathrm{B}$ & $\mathrm{C}$ & $\mathrm{A}$ & $\mathrm{B}$ & $\mathrm{C}$ & $\mathrm{A}$ & $\mathrm{B}$ & $\mathrm{C}$ \\
1 & 55 & 64 & 31 & 58 & 66 & 33 & 56 & 65 & 33 & 56 & 65 & 33 & 56 & 65 & 33 \\
2 & 55 & 55 & 37 & 69 & 74 & 48 & 66 & 61 & 48 & 66 & 61 & 48 & 65 & 60 & 49 \\
3 & 53 & 43 & 48 & 90 & 90 & 80 & 84 & 63 & 80 & 85 & 64 & 82 & 77 & 59 & 82 \\
4 & 28 & 7 & 21 & 75 & 63 & 76 & 78 & 61 & 76 & 85 & 73 & 98 & 68 & 51 & 89 \\
5 & 2 & 0 & 9 & 34 & 26 & 65 & 43 & 23 & 65 & 81 & 49 & 94 & 29 & 15 & 69 \\
6 & 0 & 0 & 8 & 28 & 11 & 53 & 11 & 9 & 53 & 28 & 32 & 93 & 1 & 8 & 55 \\
7 & 0 & 0 & 0 & 31 & 6 & 17 & 0 & 4 & 17 & 1 & 27 & 41 & 0 & 4 & 4 \\
8 & 0 & 0 & 0 & 48 & 58 & 31 & 1 & 1 & 31 & 1 & 2 & 54 & 0 & 0 & 19 \\
9 & 0 & 3 & 11 & 66 & 45 & 63 & 2 & 15 & 63 & 2 & 19 & 98 & 0 & 10 & 53 \\
10 & 10 & 9 & 49 & 77 & 71 & 83 & 53 & 35 & 83 & 63 & 44 & 96 & 22 & 28 & 86 \\
11 & 41 & 36 & 45 & 95 & 98 & 80 & 74 & 67 & 80 & 74 & 67 & 80 & 59 & 54 & 77 \\
12 & 55 & 67 & 39 & 76 & 71 & 48 & 65 & 70 & 48 & 65 & 70 & 48 & 62 & 69 & 48 \\
\hline
\end{tabular}

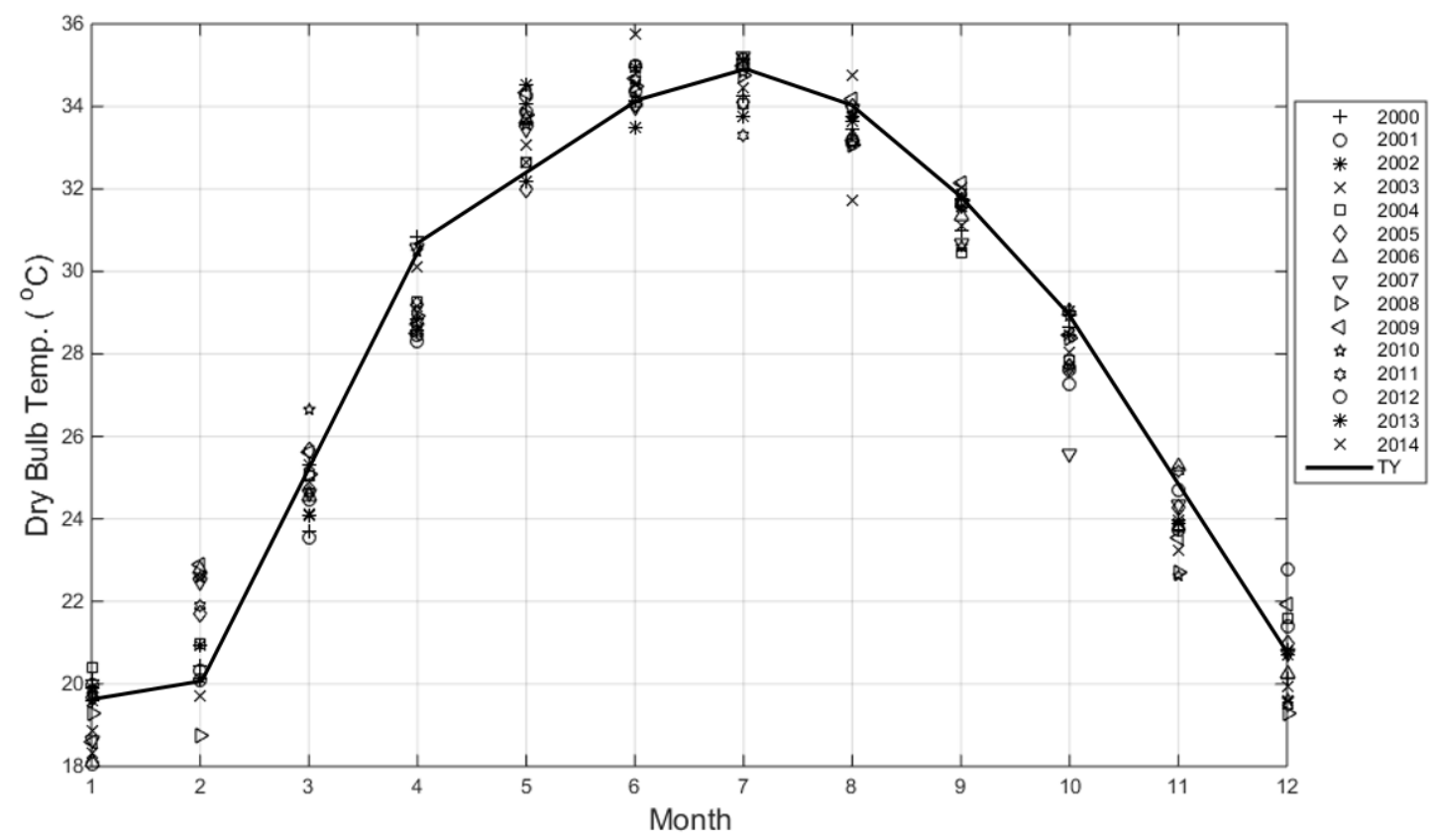

Figure 5. The typical year based on all parameters using TMY2/3 approach. 
It is clear that the selection of the typical years for each month has changed. Figure 6 shows more conformity between the typical year and the crowd of the means of all months in the record since the mean temperature is assigned a higher weight. However, deviation is still present in both figures because of the existence of other parameters. This comparison shows the importance of only considering the relevant parameters in the intended purpose.

\section{Conclusion}

Typical meteorological years were developed for Seeb area in Muscat Governorate, Oman using different sources of weather data and different development approaches. Each developed TMY is used for analyzing energy consumption in a building and the variation in the accuracies of the different sources has shown greater impact than the variation resulting from using different approaches for the same data source. Hence, the accuracy of the source data is the main playing factor. Moreover, although using different TMY development methods has minimal impact on annual energy consumption, the impact can be significant on the capital cost which is due to the fact that equipment sizing is greatly dependent on the peak points of the external heat gain. The TMY is composed of typical months in the record and the selection of these months are based on calculations of averages where peak points are hardly detectable.

Until very recently, weather data was very scarce in Oman and most works were based on records from 1985 to 2001 which had many gaps and anomalies. When it is based on this record, the analysis of the presented case study has shown significant difference in capital cost and yearly energy consumption compared to the analysis based on the recent record which is more accurate and well-kept. Hence, with the development of more accurate measurement and logging technologies, it is recommended that TMYs be redeveloped from time to time to reassure their reliability.

Bioclimatic charts were developed using the different TMYs for studying the applicability of the different passive cooling strategies. Since bioclimatic charts only involve dry bulb temperature and dew point, involving solar radiation in developing their typical year should involve disturbance to their accuracy. This fact is proven when comparing the applicability of passive cooling strategies based on TMYs developed with and without solar radiation. The involvement of solar radiation poses significant variation when the TMYs are based on the same set of historical record. It is hence recommended that for bioclimatic charts and passive cooling, TMYs should be developed without solar radiation.

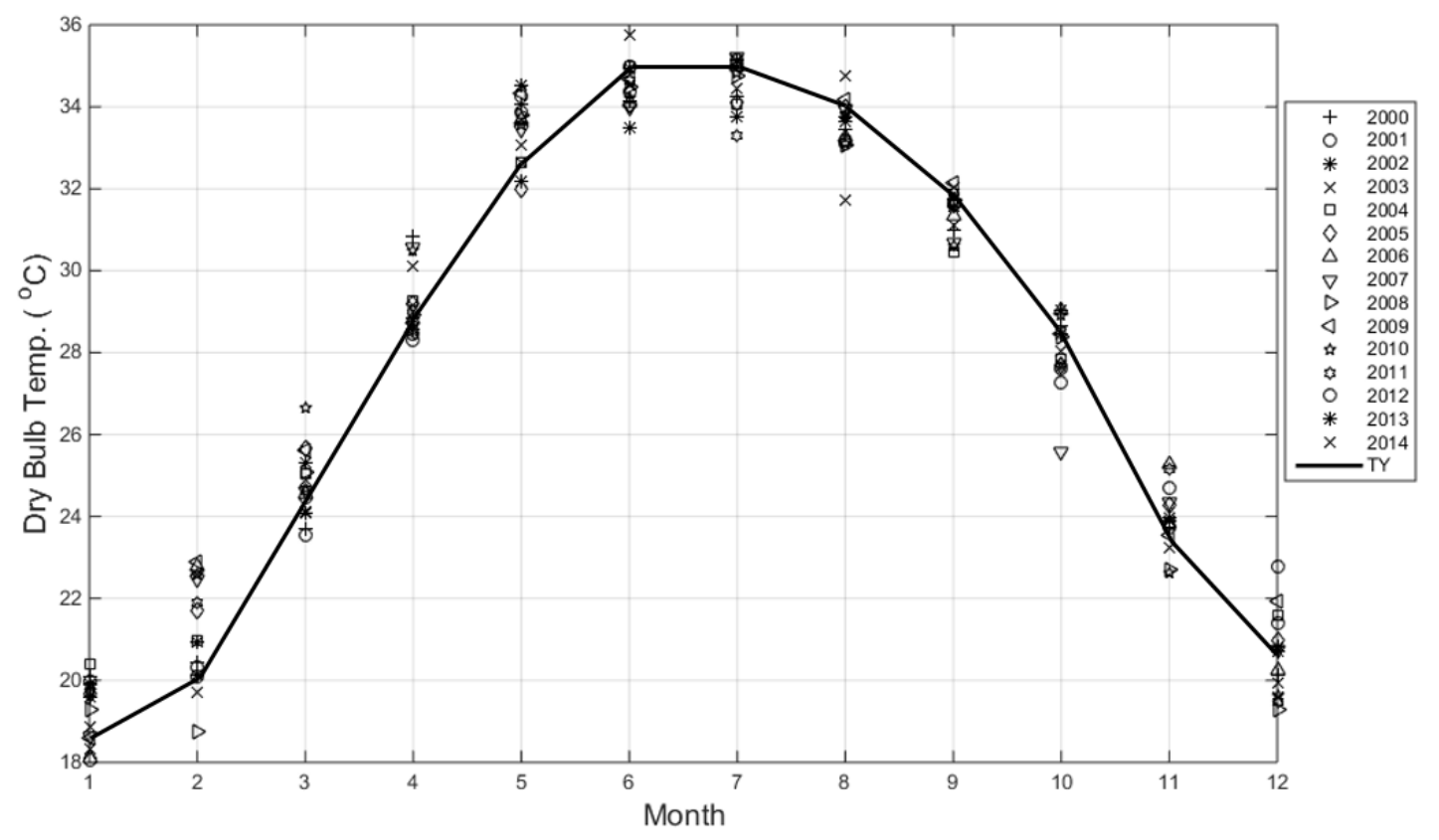

Figure 6. The typical year based on dry bulb and dew point temperatures only. 


\section{Conflict of Interest}

The authors declare no conflicts of interest.

\section{Funding}

No funding was received for this project.

\section{References}

Al-Azri N (2016), Development of a typical meteorological year based on temperature and humidity for passive cooling applications. Energy for Sustainable Development 33: 61-74.

Al-Azri N, Zurigat YH, Al-Rawahi N (2013), Development of bioclimatic chart for passive building design. International Journal of Sustainable Energy 32(6): 713-723.

Al-Hashim A (2013), Masters Report: Guidelines for Improving the Thermal Performance of Typical Residential Houses in Oman: The Case of Integrating shading into Building Codes in Muscat City. (Master's Report), The University of Arizona.

ASHRAE (2015).

URL: https://www.ashrae.org/resources--publications/bookstore/iwec2[Accessed: May/ 23/2015].

Chakraborty D, Elzarka H, Bhatnagar R (2016), Generation of accurate weather files using a hybrid machine learning methodology for design and analysis of sustainable and resilient buildings. Sustainable Cities and Society 24: 33-41.

Clarke JA (2001), Energy simulation in building design (2nd ed.). London ButterworthHeinemann.

Crawley D, Winkelmam F, Lawrie L, Pedersen C (1999). Energyplus: A new-generation building energy simulation program. Building Energy Simulation User News 20(1).

Erba S, Causone F, Armani R (2017), The effect of weather datasets on building energy simulation

output. 9th International Conference on Sustainability in Energy and Buildings, SEB -17, 5-7 July 2017, Chania, Crete, Greece.

Givoni B (1992), Comfort, climate analysis and building design guidelines. Energy and Buildings 18(1): 11-23. doi: http://dx.doi.org/10.1016/0378-7788 90047-K.

Givoni B (1994). Passive Low Energy Cooling of Buildings: Wiley.
Habte A, Lopez A, Sengupta M, Wilcox S (2014), Temporal and spatial comparison of gridded TMY, TDY, and TGY data sets (Report No. NREL/TP-5D00-60886 United States10.2172/ 1126297Mon May 12 11:16:12 EDT 2014NRELEnglish). http://www.osti. gov/ scitech//servlets/purl/1126297/.

Hall I, Prairie R, Anderson H, Boes E (1978), Generation of typical meteorological years for 26 SOLMET stations. SAND78-1601. Albuquerque, NM: Sandia National Laboratories.

Holmes MJ, Hitchin ER (1978), An example weather year for the calculation of energy demand in buildings. CIBSE Building Services Eng, 45(2): 186-189.

Huang J (1998), Impact of different weather data on simulated residential heating and cooling loads. ASHRAE Transactions 104(2): 516-527.

Lawrence Berkeley National Laboratory, and James J. Hirsch \& Associates (JJH). (1998). Overview of DOE-2.2, Report by Simulation Research Group.

Levermore GJ, Doylend NO (2002), North American and European hourly based weather data and methods for HVAC building energy analyses and design by simulation. ASHRAE Transactions, 108(2): 1053-1062.

Lomas KJ, Fiala D, Cook MJ, Cropper P.C (2004), Building bioclimatic charts for nondomestic buildings and passive downdraught evaporative cooling. Building and Environment 39(6): 661-676. doi: http://dx.doi.org/10.1016/j.buildenv.2003.1 2.011

Marion W, Urban K (1995), User's Manual for TMY2s Typical Meteorological Years (Report No. NREL/SP-463-7668).

Meteonorm 7. (2015). URL: http:// meteonorm.com. [Accessed: May/23/2015]

National Climate Data Center, (1976), Test Reference Year (TRY), Tape Reference Manual (Report No. TD-9706 ). Asheville, North Carolina.

Olgyay V, Olgyay A (1963), Design with climate: bioclimatic approach to architectural regionalism: Some chapters based on cooperative research with Aladar Olgyay: Princeton University Press.

Petrakis M, Lykoudis S, Kassomenos P (1996), A software tool for the creation of a typical meteorological year. Environmental Software 11(4): 221-227. doi: http://dx.doi.org /10.1016/S0266-9838(96)00006-8. 
Pissimanis D, Karras G, Notaridou V, Gavra K (1988), The generation of a "typical meteorological year" for the city of Athens. Solar Energy 40(5): 405-411. doi: http://dx.doi.org/10.1016/0038-092X (88)90095-3.

Sawaqed NM, Zurigat YH, Al-Hinai H (2005), A step-by-step application of sandia method in developing typical meteorological years for different locations in Oman. International Journal of Energy Research 29(8): 723-737. doi: 10.1002/er.1078.

Stoffel TL, Rymes MD (1998), Production of the weather year for energy calculations version 2 (WYEC2) data files. ASHRAE Transactions 104(2).
Watson D (1981), Analysis of weather data for determining appropriate climate control strategies in architectural design. In $R$. Haisley (Ed.), International Passive and Hybrid Cooling Conference. Miami Beach, Florida (U.S.A.): Solar Energy Association.

WATSUN Simulation Laboratory. (1992). Engineering Data sets of hourly weather observations in WYEC2 format (WYEC2 files) and Canadian weather for energy calculations (CWEC files), User's Manual, Prepared for Environment Canada Atmosphere Environment Service and National Research Council Canada. Waterloo, Ontario.

Wilcox S, and Marion W (2008). Users Manual for TMY3 Data Sets (Revised) (Report No. NREL/TP-581-43156). 